\title{
Н.М. Богдан
}

\section{ЕФЕКТИВНІСТЬ КОМПЛЕКСНОЇ МЕДИЧНОЇ РЕАБІЛІТАЦІЇ ХВОРИХ, ЩО СТРАЖДАЮТЬ НА ОСТЕОАРТРОЗ КОЛІННИХ СУГЛОБІВ ІЗ СУПУТНІМ МЕТАБОЛІЧНИМ СИНДРОМОМ}

Одеський національний медичний університет, м. Одеса

\begin{abstract}
Резюме. Остеоартроз (ОА) - найбільш поширена патологія опорно-рухового апарату. Більше 10 \% населення планети страждає цим захворюванням. На розвиток ОА впливає метаболічний синдром (МC), що призводить до перевантаження функціонування колінних суглобів, і $€$ однією 3 основних причин передчасної втрати працездатності та інвалідизації населення. Лікувальна фізкультура в поєднанні з природними та преформованими фізичними факторами в комплексної медичної реабілітації ОА і МС є важливим функціональним методом відновного лікування даної патології. Проведено лікування у 30 пацієнтів середнього та літнього віку з МС, які страждають на ОА. У групі пацієн-
\end{abstract}

Вступ. Остеоартроз (ОА) - це хронічне прогресуюче дегенеративне захворювання суглобів, що характеризується деградацією суглобового хряща 3 подальшими змінами в субхондральній кістковій тканині й розвитком крайових остеофітів, що призводить до втрати хряща та супутнього ураження інших компонентів суглоба (синовіальної оболонки, зв'язок) $[1,2]$. Загалом $10-15 \%$ осіб віком понад 60 років хворіють на остеоартроз, а зважаючи на істотне постаріння населення планети, він стає все більш актуальним захворюванням $[1,2,4]$. Щодо впливу на загальний стан здоров'я ОА посідає четверте місце серед усіх захворювань у жінок і восьме - у чоловіків, а як причина недієздатності в літньому віці - друге місце після захворювань серцевосудинної системи. Хоча розвиток остеоартрозу й не впливає на життєвий прогноз, дана патологія $€$ однією з основних причин передчасної втрати працездатності та інвалідизації, а також виникнення хронічного больового синдрому, що значно знижує якість життя пацієнтів $[4,5]$.

На сьогодні остеоартроз розглядають як системну метаболічну хворобу, яка є частиною метаболічного синдрому (МС). Метаболічний синдром - це патологічний стан, для якого характерний розвиток абдомінального ожиріння, дисліпідемії, артеріальної гіпертензії та порушення вуглеводного обміну (феномен інсулінорезистентності) $[3,7,8]$. Надлишкова маса тіла, як один із проявів МC, є важливим фактором ризику розвитку остеоартрозу, переважно осьових суглобів, завдяки наявності не тільки надмірного механічного навантаження на суглоби, а й обмеженням фізичної активності, що призводить до слабкості сухожилково-м'язового апарату та порушення конгруентності суглобових поверхонь. Збільшення маси тіла створює умови перевантаження для функціонування колінних суглобів $[3,7,8]$. тів, які приймали комплексну реабілітаційну терапію із застосуванням лікувальних фізичних вправ у басейні та електрофорезу неокарипазином, на фоні стандартної медикаментозної протизапальної та знеболювальної терапії отриманий виражений стійкий ефект щодо купірування больового синдрому, зменшення ступеня вираженості запальних реакцій, збільшення рухливості суглобів, а також покращення якості життя, ніж у групі пацієнтів, які приймали хондропротектори та нестероїдні протизапальні препарати.

Ключові слова: остеоартроз, метаболічний синдром, комплексна медична реабілітація.

Використання засобів та методів фізичної реабілітації має важливе значення, оскільки вони направлені на стимуляцію механізмів компенсації та резервних можливостей організму, нормалізації життєво важливих функцій. На сьогодні в реабілітації пацієнтів з ОА використовують природні та преформовані фізичні фактори й такі методики: рефлексотерапію, бальнео- та грязелікування, електро-, магніто- та лазеротерапію, а також ортопедичне лікування та лікувальну фізкультуру (ЛФК). Остання є важливим функціональним методом відновлювального лікування остеоартрозу колінного та кульшового суглобів, оскільки даний метод сприяє розвитку компенсаторно-пристосувальних механізмів, направлених на відновлення та покращення функції суглоба $[3,5,6]$.

Мета дослідження. Оцінити ефективність комплексної медичної реабілітації хворих, що страждають на остеоартроз колінних суглобів із супутнім метаболічним синдромом.

Матеріал і методи. У дослідження увійшли 30 пацієнтів (18 - жінок та 12 - чоловіків), віком від 50 до 70 років, які страждають на ОА (рентгенологічні стадії II, III) та МС (індекс маси

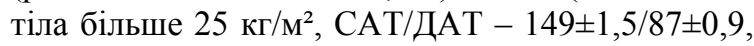

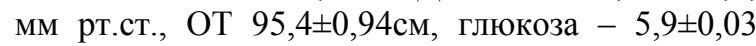

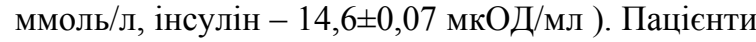
розподілені на дві групи за способом лікування. Усім пацієнтам II групи (15 осіб - із них 6 чоловіків та 9 жінок) призначалося на фоні стандартної медикаментозної протизапальної та знеболювальної терапії лікувальні фізичні вправи в басейні (при $\mathrm{t}$ води $30^{\circ} \mathrm{C}$, тривалістю занять - 20 хв, кожного дня курсом 12 процедур), а потім електрофорез неокарипазином (за допомогою синусоїдальних модульованих струмів (СМС) на випрямленому режимі $50 \% 50$ Гц, інтенсивністю струму 0,04-0,06 мА/см², тривалістю 10-15 хв, щоденно 
курсом 14-16 процедур ), повторенням курсу через три місяці впродовж двох років. Пацієнтам I групи проводилося лікування тільки нестероїдними протизапальними препаратами (мелоксикам дозою 15 мг кожен день, один раз на добу) та хондропротекторами (піаскледин 3001 т на добу, впродовж трьох місяців). До та після лікування всім хворим проводили оцінку больового синдрому за шкалою ВАШ, для оцінки болю та зниження якості життя застосовували альгофункціональний індекс Лекена, якість життя визначали за допомогою стандартного опитувальника шкали EuroQol5D ( що кількісно оцінював якість життя за кількома позиціями: ходьба, самообслуговування, повсякденна активність, біль/дискомфорт, неспокій/ депресія), рентгенологічне дослідження колінних суглобів, вимірювання кутоміром рухливості колінних суглобів та біохімічне дослідження крові (показники запалення, ліпідограма). Обробку результатів проводили за допомогою пакета аналізів у системі Microsoft Excel. Достовірність відмінності одержаних параметричних даних досліджували за допомогою двобічного $t$ критерію Стьюдента.
Результати дослідження та їх обговорення. Після проведеної комплексної медичної реабілітації із застосуванням лікувальних фізичних вправ у басейні та електрофорезу неокарипазином намітилась суттєва різниця у клінічному перебігу ОА колінних суглобів із супутнім метаболічним синдромом у двох групах спостереження, які отримували різну терапію.

Зокрема, зменшилася вираженість запального синдрому (за біохімічними даними показників запалення) у досліджених групах, а саме у II групі, де було проведено комплексне лікування із застосуванням лікувальних фізичних вправ у басейні та електрофорезу неокарипазином (табл. 1).

При оцінці параметрів ліпідного обміну, за даними біохімічного дослідження, (ліпідограма) у пацієнтів різних груп до та після лікування зменшення показників ліпідного обміну спостерігалося в основній групі пацієнтів, де застосувувалися лікувальні фізичні вправи у басейні та електрофорез неокарипазином (табл. 2).

Оцінка больового синдрому за шкалою ВАШ, альгофункціонального індексу Лекена та

Таблиця 1

Порівняна оцінка гострофазових показників запалення у паціснтів, які страждають на остеоартроз із супутнім метаболічним синдромом у різних групах проведеної терапії

\begin{tabular}{|c|c|c|c|c|c|}
\hline Показник & \multicolumn{2}{|c|}{ І група $\mathrm{n}=15$} & \multicolumn{2}{c|}{ II група $\mathrm{n}=15$} & $\mathrm{p}$ \\
\hline & До лікування & Після лікування & До лікування & Після лікування & \\
\hline СРБ & +++ & ++ & +++ & ++ або + & \\
\hline Фібриноген, г/л & $5,23 \pm 0,05$ & $4,24 \pm 0,05$ & $5,12 \pm 0,03$ & $3,73 \pm 0,03$ & $>0,05$ \\
\hline Серомукоїд, од. & $0,320 \pm 0,002$ & $0,260 \pm 0,002$ & $0,320 \pm 0,003$ & $0,230 \pm 0,004$ & $<0,05$ \\
\hline ШОЕ, мм/год & $34,0 \pm 1,06$ & $24,0 \pm 1,06$ & $32,0 \pm 1,02$ & $15,0 \pm 1,02$ & $<0,05$ \\
\hline
\end{tabular}

Таблиця 2

Показники ліпідного обміну в пацієнтів різних груп до та після лікування $(\mathbf{p} \leq 0,05)$

\begin{tabular}{|c|c|c|c|c|}
\hline \multirow{2}{*}{ Показник } & \multicolumn{2}{|c|}{$\mathrm{I}$ група } & \multicolumn{2}{c|}{$\begin{array}{c}\text { II група } \\
\mathrm{n}=30 \mathrm{M} \pm \mathrm{m}\end{array}$} \\
\hline & До лікування & Після лікування & До лікування & Після лікування \\
\hline ЗХ, ммоль/л & $5,8 \pm 0,02$ & $5,5 \pm 0,02$ & $5,6 \pm 0,02$ & $5,3 \pm 0,02$ \\
\hline ХС ЛПНЩ, ммоль/л & $5,11 \pm 0,05$ & $4,54 \pm 0,05$ & $5,12 \pm 0,05$ & $4,56 \pm 0,05$ \\
\hline ХСЛПВЩ, ммоль/л & $1,19 \pm 0,07$ & $1,18 \pm 0,07$ & $1,19 \pm 0,07$ & $1,17 \pm 0,07$ \\
\hline ТГ ммоль/л & $1,8 \pm 0,04$ & $1,7 \pm 0,03$ & $1,9 \pm 0,04$ & $1,7 \pm 0,03$ \\
\hline $\begin{array}{c}\text { Коефіцієнт атерогенно- } \\
\text { сті (КА) }\end{array}$ & $3,95 \pm 0,45$ & $3,02 \pm 0,10$ & $3,87 \pm 0,41$ & $3,12 \pm 0,13$ \\
\hline
\end{tabular}

Таблиця 3

Інтенсивність больового синдрому та якість життя у хворих на остеоартроз у динамиці лікування $(\mathbf{p}<0,05)$

\begin{tabular}{|c|c|c|c|c|}
\hline $\begin{array}{c}\text { Показники больового синдрому та } \\
\text { якості життя }\end{array}$ & \multicolumn{2}{|c|}{$\begin{array}{c}\text { I група } \\
\mathrm{n}=30 \mathrm{M} \pm \mathrm{m}\end{array}$} & \multicolumn{2}{c|}{$\begin{array}{c}\text { II група } \\
\mathrm{n}=30 \mathrm{M} \pm \mathrm{m}\end{array}$} \\
\hline & До лікування & Після лікування & До лікування & Після лікування \\
\hline Інтенсивність болю за ВАШ (в см) & $6,13 \pm 0,09$ & $3,75 \pm 0,04$ & $4,92 \pm 0,07$ & $2,53 \pm 0,03$ \\
\hline $\begin{array}{c}\text { Альгофункціональний індекс Леке- } \\
\text { на (бали) }\end{array}$ & $15,6 \pm 1,03$ & $7,3 \pm 0,04$ & $11,3 \pm 1,01$ & $6,2 \pm 0,09$ \\
\hline Індекс EuroQol-5D & $8,1 \pm 0,08$ & $3,5 \pm 0,07$ & $6,1 \pm 0,06$ & $2,9 \pm 0,05$ \\
\hline
\end{tabular}




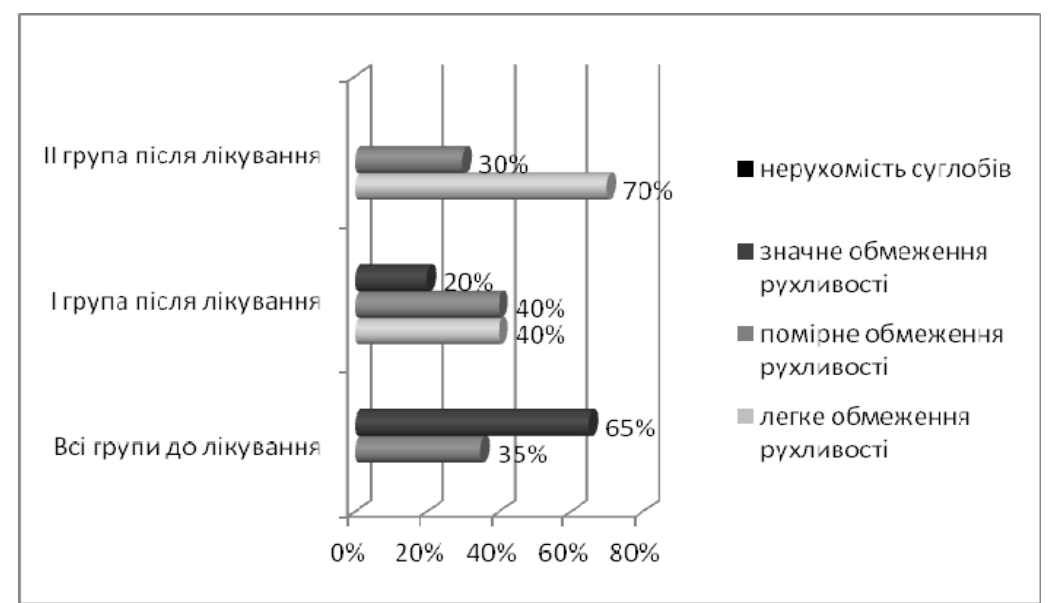

Рис. Показники рухливості колінних суглобів визначені за допомогою кутоміра у пацієнтів різних груп до та після лікування $(\mathrm{p} \leq 0,05)$

якість життя за допомогою стандартного опитувальника шкали EuroQol-5D до та після проведеного лікування в зазначених групах хворих на ОА колінних суглобів наведені в таблиці 3 .

Оцінка рухливості колінних суглобів здійснена за допомогою кутоміра в пацієнтів різних груп до та після лікування. Вагоміше збільшення рухливості колінних суглобів спостерігалося в тій групі пацієнтів, де застосувувалися лікувальні фізичні вправи та електрофорез неокарипазином (рис.).

\section{Висновки}

1. При застосуванні лікувальних фізичних вправ у басейні та електрофорезу неокарипазином у комплексній медичній реабілітації хворих, що страждають на остеоартроз колінних суглобів із супутнім метаболічним синдромом, всі гострофазові показники запалення знизилися у 2 рази; больовий синдром за шкалою ВАШ знизився майже у 2 рази.

2. У $54 \%(\mathrm{p} \leq 0,05)$ пацієнтів, яким застосовували лікувальні фізичні вправи у басейні в поєднанні з електрофорезом неокарипазином, спостерігалися уповільнення ураження колінних суглобів, підвищення працездатності та покращення якості життя.

Перспективи подальших досліджень. Комплексна медична реабілітація із застосуванням лікувальних фізичних вправ у басейні та електрофорез неокарипазином у хворих на остеоартроз колінних суглобів із супутнім метаболічним синдромом - ефективний метод лікування та реабілітації пацієнтів зазначеної категорії, який сприяє розвитку компенсаторно-пристосувальних механізмів, направлених на відновлення та покращення функції суглоба. Цей метод $є$ удосконалення існуючої медикаментозної терапії, раціональним у використанні, та $є$ економічно-доступним способом лікування. Спираючись на отримані дані, у подальшому можливе застосування в комплексній медичній реабілітації пацієнтів, які страждають на остеоартроз колінних суглобів із супутнім метаболічним синдромом, 3 подальшим вивченням віддалених результатів

\section{Література}

1. Бур'янов О.А. Остеоартроз: питання патогенезу, діагностики та лікування / О.А. Бур'янов // Здоров'я України. -2009 . - № 23 (228). - С. 63.

2. Коваленко В.М. Остеоартроз / В.М. Коваленко, О.П. Борткевич. - К.: МОРІОН, 2010. -113 c.

3. Лечебная физкультура в комплексном лечении остеоартроза коленных суставов / Н.В. Григорьева, В.В. Поворознюк, Р.О. Банникова [и др.] // Боль. Суставы. Позвоночник. - 2011. - № 2 (02). - С. 35-40.

4. Поворознюк В.В. Захворювання кістково-м'язової системи в людей різного віку / Поворознюк В.В. - К., 2011. - Т. 2. -360 c.

5. Пшетаковский И.Л. Артрозы / И.Л. Пшетаковский. О.: Астропринт, 2004. - С. 101-116, 228-231, 241-249.

6. Ребров А.П. Новые возможности в лечении остеоартроза / А,П. Ребров, И.А. Романова // Здоров'я України. - 2013. - № 4. - С. 84.

7. Соколова Л.К. Метаболический синдром: клиника, критерии диагностики, принципы терапии / Л.К. Соколова // Междунар. эндокринол. ж. - 2010. - № 1 (25). - C. 36.

8. Ткаченко М.В. Патогенетичні механізми розвитку деформуючого остеоартрозу у поєднанні з метаболічним синдромом / М.В. Ткаченко // Укр. ревматол. ж. 2007. - № 4 (38). - C. 86.

\section{ЭФФЕКТИВНОСТЬ КОМПЛЕКСНОЙ МЕДИЦИНСКОЙ РЕАБИЛИТАЦИИ БОЛЬНЫХ, СТРАДАЮЩИХ ОСТЕОАРТРОЗОМ КОЛЕННЫХ СУСТАВОВ ИЗ СОПУТСТВУЮЩИМ МЕТАБОЛИЧЕСКИМ СИНДРОМОМ}

\section{Н.М. Богдан}

Резюме. Остеоартроз (ОА) - наиболее распространенная патология опорно-двигательного аппарата. Более 10 \% населения планеты страдает этим заболеванием. На развитие ОА влияет метаболический синдром (МС), что приводит к перегрузке функционирования коленных суставов, и является одной из основных причин преждевременной потери трудоспособности и инвалидизации населения. Лечебная физкультура в сочетании с природными и преформированными физическими факторами в комплексной медицинской реабилитации ОА и МС является важ- 
ным функциональным методом восстановительного лечения данной патологии. Проведено лечение у 30 пациентов среднего и пожилого возраста с МС, страдающих ОА. В группе больных, принимавших комплексную реабилитационную терапию с применением лечебных физических упражнений в бассейне и электрофореза неокарипазином на фоне стандартной медикаментозной противовоспалительной и обезболивающей терапии, получен выраженный стойкий эффект в отношении купирования болевого синдрома, уменьшение степени выраженности воспалительных реакций, увеличение подвижности суставов, а также улучшение качества жизни, чем в группе пациентов, принимавших хондропротекторы и нестероидные противовоспалительные препараты.

Ключевые слова: остеоартроз, метаболический синдром, комплексная медицинская реабилитация.

\section{EFFECTIVENESS OF COMPLEX MEDICAL REHABILITATION OF PATIENTS SUFFERING FROM OSTEOARTHRITIS OF THE KNEE JOINT WITH CONCOMITANT METABOLIC SYNDROME}

\section{N.M. Bohdan}

Abstract. Osteoarthritis (OA) is the most common pathology of the musculoskeletal system. More than $10 \%$ of the world population suffer from this disease. The development of OA affects metabolic syndrome (MS), which leads to an overload of the knee operation, and is one of the main causes of premature disability and population disability. Therapeutic exercises combined with natural and preformed physical factors in the complex rehabilitation OA and MS is an important method of functional restoration treatment of this disease. We treated 30 patients of middle and old age with MS suffering from OA. In patients treated with comprehensive rehabilitation therapy using therapeutic exercise in the pool and electrophoresis with neokarypazyn on a background of standard drug anti-inflammatory and analgesic treatment we obtained expressed sustained effect on the relief of pain, reducing the severity of inflammatory reactions, increase joint mobility and improve quality life than in patients treated with NSAIDs and chondroprotectors.

Key words: osteoarthritis, metabolic syndrome, complex medical rehabilitation

National Medical University (Odesa)

Рецензент - проф. О.І. Волошин

Buk. Med. Herald. - 2016. - Vol. 20, № 3 (79). - P. 14-17

Надійшла до редакції 27.04.2016 року

(c) Н.М. Богдан, 2016 